Article

\title{
An assessment of air and water pollution accrued from stone quarrying in Mukono District, Central Uganda
}

\author{
Hilary Bakamwesiga ${ }^{*}$, William Mugisha ${ }^{2}$, Yeeko Kisira $^{3}$, and Andrew Muwanga ${ }^{4}$
}

1 Department of Civil and Environmental Engineering, School of Engineering, Collage of Engineering, Design, Art and Technology (CEDAT), Makerere University, P.O Box 7062, Kampala; hbakamwesiga@gmail.com

2 Department of Environmental Management, Makerere University, P.O Box 7062, Kampala; mugisha.william1@gmail.com

3 Department of Geography, Geo-informatics and Climatic Sciences, Makerere University; School of Forestry, Environment, and Geographical Sciences, College of Agricultural and Environmental Sciences, Makerere University, P.O Box 7062,

Kampala; kisirayeeko@gmail.com

4 Department of Geology and Petroleum Studies, Makerere University, P. O Box 7062, Kampala; azmuwanga57@gmail.com

* Correspondence: hbakamwesiga@gmail.com

\begin{abstract}
The unquenchable demand for rock materials has attracted many companies within the building and construction sector to invest in stone quarrying. However, this has brought about the environmental impacts with health threats to people. There is a paucity of information about the magnitude of pollution on air and water and how it varies with quarry sites. This study therefore investigated the physical impacts of quarrying on air and water and explored the in-situ mitigations to undesirable effects due to stone quarrying. Four active quarry sites were identified. Field measurements of dust (particulate matter) was conducted within the four quarry sites and in the nearby community. Water samples were collected from quarry pits and nearby shallow wells for laboratory analysis of water quality. Statistical Analysis of Variance (ANOVA) was used to test for differences in pollution across the four studied sites. Results revealed that, amidst use of wet crushing and water sprinkling on bare surfaces, dust emission was higher than the recommended permissible standards levels with a significant variation across the quarry sites with ANOVA ( $P$-value $=0.003$ ) for PM2.5 and (P-value=0.04366) for PM10. Water pollution was mainly contributed by the nonpermissive levels of nitrates, chromium, and $\mathrm{pH}$. Polluted air and water are associated with sparking off health threats to the users in the community. In conclusion, quarry companies should strengthen the already existing mitigation of dust suppression. The study recommends additional measures such as treating quarry pit water before discharging to the open environment
\end{abstract}

Keywords: Stone quarrying, air, water, pollution, mitigation

\section{Introduction}

In Africa, very strong impetus has recently been given to infrastructure development especially roads, power generation dams and other construction ventures [1]. Meeting the demand for such developments requires harnessing potential sources of raw materials such as aggregates, gravel, sand and limestone[2]. The ever increasing demand for such raw material has led to increased quarrying activities in many parts of the country, which is a clear indication that rock extraction activity is a significant form of earth resource exploitation that is viewed to be a financially rewarding occupation to those involved, in terms of employment and providing income [3,4]. The activity has also contributed to the improvement of infrastructure such as roads ultimately left to local communities after decommissioning of the quarries thus infrastructure development [5]. However, it is conceived that many rock extraction companies in various parts of Africa still use archaic and unregulated methods and; they do not effectively follow the stipulated conditions in the respective permits/licenses from the authorizing agencies. This makes monitoring of their activities and enforcement of mineral extraction regulations very difficult $[3,6,7]$. The consequences of such irregularities come with great environmental, health, and social costs 
to the host communities[8]. There is thus a great public outcry against the quarry proprietors since most of these operators' main target is to maximize profit with less concern on the harm that they pose to the environment and the people [9].

According to [10] four million deaths are reported annually from acute respiratory problems in developing countries owing to aggravated pollution from stone crushing and blasting. Plants near stone quarry areas tend to show heavy interference of photosynthesis processes because of high intensity of dust although this reduces with distance and differ with plant species [11]. On the other hand, cases of child labour have been reported in various quarry sites a matter that has been of great concern to workers' unions and activists in the country. The Employment Act, 2006 governs labour in quarrying industry and this provides for the protection of children and guides that a child under 12 years are not allowed to be employed under any circumstances [12].

Uganda's mining and quarrying industry is growing at a rate of 11 percent per annum and this has offered employment to about 300,000 Ugandans and created other livelihood opportunities along the mining value chain [13,14]. Irrespective of improving people's livelihoods, mineral extraction and rock quarrying activities often impart long-term environment and social-economic footprints in areas in which it is carried out $[7,15]$. Several activities or stages of rock extraction normally result into permanent vegetation loss and destruction of habitat, threats to health and safety of host communities, damage to cultural sites, and eventual displacement of the community [16]. On the other hand, NEMA a coordinating, monitoring, regulatory and supervisory body for all activities relating to environment in Uganda, has been concerned with the negative implications. This applies especially to sites left without being rehabilitated observing that abandoned pits deface landscape and make the soil structure weak. Therefore, to transform the extraction subsector into a sustainable livelihood option for the population, there is need to support and promote awareness creation of Occupational Health and Safety Policy. It is also important to support formulation of policies that compel quarry developers to restore sites of rock extraction $[4,13]$.

\subsection{Quarrying and Air pollution}

Air pollution resulting from different extraction activities triggers airborne particulate matter and black smoke [17]. Stockpiles of fine material from crushing can be a source of airborne dust. The situation may be worsened if piles are highly exposed to wind erosion [18]. Dust may also originate from haulage trucks and conveyors inside the quarry sites [5].

Particulate matter is defined as air pollutants that comprise of suspended particles in air, varying in composition and size, resulting from various anthropogenic activities [19]. Particulate matter (PM) or fugitive dust is the primary source of air pollution in quarries mainly from rock blasting and crushing activities. In this case, the extent of pollution will depend on the local microclimate conditions $[3,10,20]$. Dust particles are dispersed by their suspension and entrainment in an airflow. Dispersal is affected by the particle size, shape and density, as well as wind speed and other climatic effects [19]. Smaller dust particles remain airborne for longer periods, dispersing widely and depositing more slowly over a wider area. Large dust particulates (greater than $30 \mu \mathrm{m}$ ), that make up the greatest proportion of dust emitted from rock extraction workings will largely deposit within 100m of sources [21]. Intermediate sized particles $(10 \mu-30 \mu \mathrm{m})$ are likely to travel up to $200-$ $500 \mathrm{~m}$. Smaller particulates (less than $10 \mu \mathrm{m}$ ) which make up a small proportion of the dust emitted from most mineral workings or quarries are only deposited slowly. Concentrations decrease rapidly on moving away from the source, due to dispersion and dilution [22].

Particulate Matter of less than $10 \mu \mathrm{m}\left(\mathrm{PM}_{10}\right)$ is the term given to the fraction of total particles suspended in the air having diameters less than $10 \mu \mathrm{m}$. The PM10 samples contain all particles less than $2.5 \mu \mathrm{m}$ in diameter $\left(\mathrm{PM}_{2.5}\right)$ as well as particles in the $2.5 \mu \mathrm{m}$ to $10 \mu \mathrm{m}$ fraction [23]. Silica content of $\mathrm{PM}_{10}$ particles rather than $\mathrm{PM}_{2.5}$ particles could lead to a 
greater crystalline silica mass due to the possible presence of silica particles in the $2.5 \mu \mathrm{m}$ to $10 \mu \mathrm{m}$ size range on the filter [24]. Particulate air pollution especially PM10 is associated with a wide range of health effects. When inhaled, it affects the respiratory and cardiovascular systems, causes asthma and later mortality. Particulates from blasting and crushing areas are considered to be more dangerous, because they are occasionally inhaled deeply into the tracts, hence settling in areas where the body's natural cleaning mechanisms cannot remove them [25,26]. Exposure to high concentrations of dust causes silicosis and fibrosis, a thickening of the lung walls leading to development of scar tissue. This scar tissue restricts the vital exchange of oxygen and carbon dioxide in the blood causing difficulty in breathing which in turn places a strain on the heart. Numerous studies suggest that health effects can occur at particulate levels that are at or below the levels permitted under national and international air quality standards. According to $\mathrm{WHO},[27]$ no evidence so far shows that there is a threshold below which particle pollution does not induce any adverse health effects, especially for the more susceptible populations.

\subsection{Quarrying and water resources}

Anthropogenic activities, such as mining and quarrying are a source of water contamination. Most pollutants are adsorbed by the suspended particles in water [28]. Access to clean water is measured by the number of people who are capable of getting it expressed in percentage of the total population [29]. Access to water reflects good health and sanitation for a particular community. Likewise, a good environment contributes to good living and assured health conditions of the human being [8]. The residents of Bumutakkude and Kiryamuli in Mukono represented by a civil society group sued a Chinese firm for allegedly violating and depriving them of their rights to access clean and safe water [30]. Furthermore, the quarry operations surrounding the natural water stream had led to the contamination of the natural stream with mud and rendered the stream inaccessible, especially during the rainy season. The verdict called upon the proprietors to establish an alternative source of water for the affected community. On the other hand, open pits within quarry sites act as water collection points/pools during heavy rains and this prompts quarry operators to empty these pits by pumping water into an open environment [31]. However, this is a challenge to the surrounding community who use shallow wells as their potential water sources because quarry wastewaters end up polluting these sources [32]. Uncontrolled dust from drilling and crushing activities normally finds its way into community water sources especially rivers and shallow wells making water unpleasant for consumption, creating a source of unending conflicts between the community and quarry owners [33].

\section{Materials and Methods}

\subsection{Description of study area}

The study was conducted in Nakisunga Sub County which lies in Mukono North County in the south of Mukono district (see Figure 1). In Nakisunga Sub County, two parishes of Namuyenje and Wankoba were selected because of being famous for both large-scale and small-scale quarrying activities. These parishes are well known for Basement Complex rocks of granite which is an essential material in the building and the construction industry thus the many quarrying activities [6,7]. The selected study area has been consistently reported to have serious health implications ranging from hearing impairments to irritation of eyes especially amongst the workers and the neighbouring communities [34].

The geology of the area can be grouped in the partially granitised formation with the greatest part of Mukono district is underlain by the Pre-Cambrian rock system. Specifically, it belongs to the Buganda-Toro system which occupies an extensive band across the South centre of the country where argillites, including phylites predominate are found [35]. This system consists of mainly wholly grainsized or high to medium metamorphosed formations, consisting of undifferentiated gneisses and elements of partly granitised and 
metamorphosed formations [35]. Microscopically, the rock is medium grained and comprising of three main minerals including biotite, quartz and feldspars. The rock is compact, tough and exhibits non schistosity. It is pale grey in colour with a pink tint in some cases.

The climate displays comparative small variations in temperature, humidity and wind throughout the year. This climate is generally humid to moist sub humid in the southern part of the district. Mean annual temperature recorded throughout the district is $20.7^{\circ} \mathrm{C}$, whilst mean annual maximum and minimum temperature levels of $26.3^{\circ} \mathrm{C}$ and $15.1^{\circ} \mathrm{C}$ respectively [36]. In terms of rainfall, the area receives a bimodal type of rainfall, with two peaks occurring in March-May and October-November, the former being the most dominant. Nakisunga Sub County had a total population of 48,320 with a household number of 12,076 contributing $8 \%$ of the total population in Mukono district [37]. The population was projected to be 56,800 people by the year 2020 with $2.8 \%$ annual population increase with 293 persons $/ \mathrm{km}^{2}$ density [38].

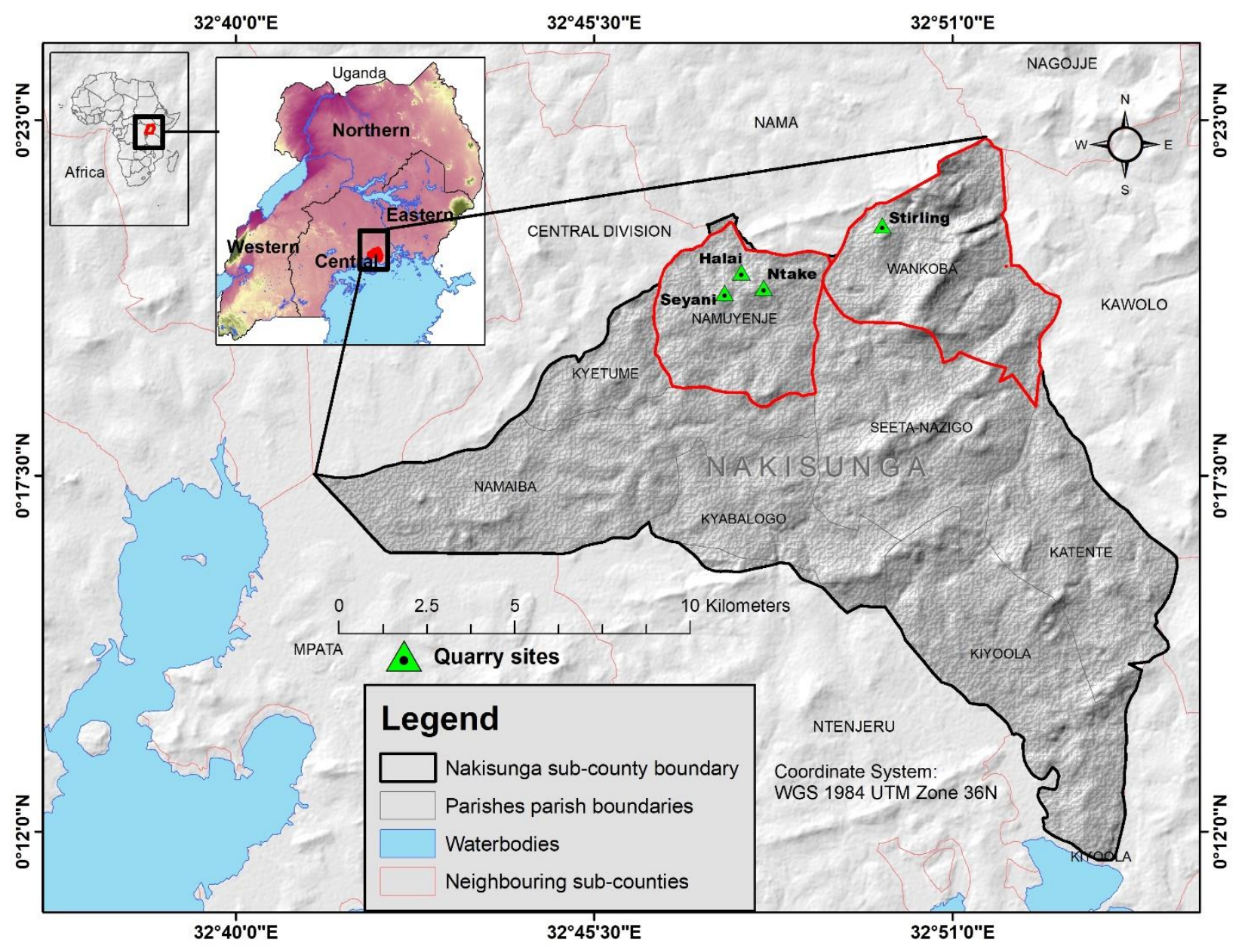

Figure 1: Location of the studied quarry sites

\subsection{Research Procedure and measurements}

Four active quarry sites were selected in Nakisunga sub-county for experimental research on air and water pollution. Using BRAMC real time air quality monitor (BR SMART-128SE), the total concentration of dust that is PM10 and PM2.5 was measured. Three replicate measurements were conducted within the quarry sites for drilling and crushing and at the neighbouring homesteads. The BRAMC instrument was placed on a 
tripod stand $2 \mathrm{~m}$ above the ground and at stability to take readings. All readings were taken after twenty (20) minutes since dust particles can remain in air for about 15 minutes [39]. Dust in form of PM10 and PM2.5 were purposively considered for study because these are commonly investigated due to their surpassing health effects on man $[10,22,40]$. For homesteads closer to the quarry sites, samples were only collected during sunny days. Only homesteads within a radius of $60 \mathrm{~m}-100 \mathrm{~m}$ were considered because majority of the homesteads were within this radius. For pits, using a one-litre plastic container, four composite water samples taking one at each quarry site, were collected. The composite samples were made up of mixed water from four sampled quarry pits at each quarry site. For the nearby community shallow wells, using one-litre containers, two samples were collected from two existing shallow wells. The obtained water samples were then taken to the laboratory for analysis and test the physical and chemical properties of water quality at Public Health and Environmental Engineering Laboratory of the Department of Civil Engineering, College of Engineering, Design and Technology Makerere University. The Standard methods as described by APHA, (1998) [41] were followed in analysis of parameters such as $\mathrm{pH}$, nitrites $\left(\mathrm{NO}_{2}\right) \mathrm{mg} / \mathrm{L}$, nitrate $\left(\mathrm{NO}_{3}\right) \mathrm{mg} / \mathrm{L}$, TDS mg/L, TSS mg/L, turbidity, iron total $(\mu \mathrm{g} / \mathrm{L})$, Zinc $(\mathrm{Zn}) \mathrm{mg} / \mathrm{L}$ and chromium $(\mathrm{Cr}) \mathrm{mg} / \mathrm{mL}$.

\section{Results}

\subsection{Air pollution}

Results of dust emission tests in Table 1 also revealed Halai quarry site emitted highest to the nearby homesteads for PM2.5 of $27 \mu \mathrm{g} / \mathrm{m}^{3}$ and $50 \mu \mathrm{g} / \mathrm{m}^{3}$ for PM10. This was followed by Seyani with $24 \mu \mathrm{g} / \mathrm{m}^{3}$ for PM2.5 and $45 \mu \mathrm{g} / \mathrm{m}^{3}$ for PM10 dust emission to the environment.

Table 1: Measurement for dust (PM) at sampled homesteads at quarry sites

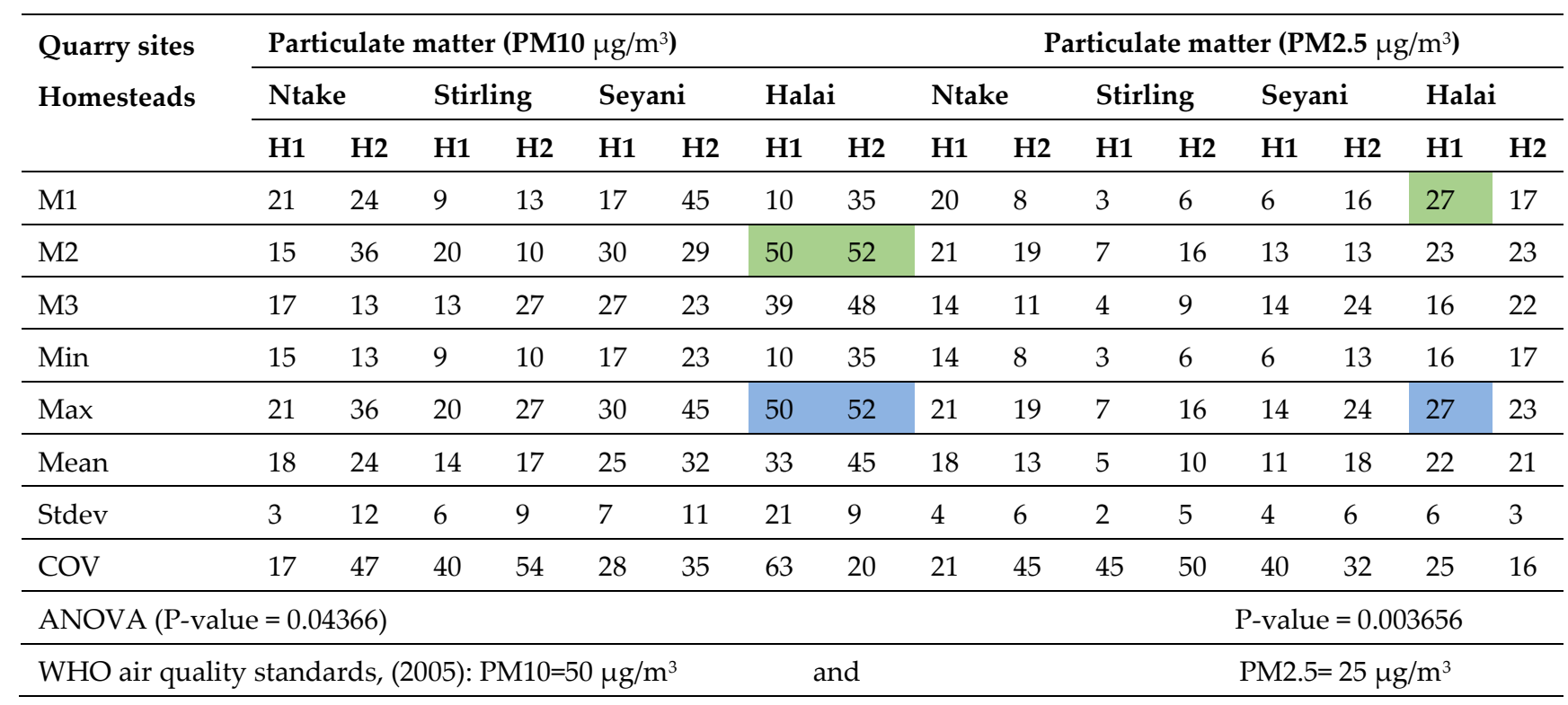

Key: $\mathrm{M}=$ Measurement, $\mathrm{H}=$ homestead, stdev =standard deviation, $\mathrm{COV}=$ coefficient of variation, Min= minimum, Max=maximum

The effect of quarry dust air pollution across the sites varied significantly especially with (ANOVA P-value $=0.003656)$ and (ANOVA P-value $=0.04366)$ for PM2.5 and PM10 respectively thus a signal for a consequent variation in air pollution across the four study quarry sites. Dust emissions at Halai was above the permissive dust levels of $50 \mu \mathrm{g} / \mathrm{m}^{3}$ for PM10 $\mu \mathrm{g} / \mathrm{m}^{3}$ and $25 \mu \mathrm{g} / \mathrm{m}^{3}$ for pm2.5 $\mu \mathrm{g} / \mathrm{m}^{3}$ advanced by WHO, (2005) [27]. 


\subsection{Variation of dust emission with quarrying processes}

Air pollution was mainly attributed dust from crushing and drilling (see Table 2). Statistical results indicated a significant variation (ANOVA $\mathrm{P}-\mathrm{v}<0.05$ ) in the dust emission for PM2.5 $\mathrm{gg} / \mathrm{m}^{3}$ between crushing and drilling for both sunny and rainy days with highest emission recorded from crushing section. There was a significant difference in dust emission between crushing and drilling (ANOVA, P-value=0.028) for sunny days with a mean dust emission levels recorded at $39.75 \mu \mathrm{g} / \mathrm{m}^{3}$ and $26.75 \mu \mathrm{g} / \mathrm{m}^{3}$ for crushing and drilling respectively. This consequently implies higher air pollution magnitude in the crushing section than the drilling section within the quarrying sections thus higher risk of health problems to the crushing operators. Dust emission between processes varied significantly and thus its implications to workers. Crushing and drilling processes had mean levels of dust emission of $29.75 \mu \mathrm{g} / \mathrm{m}^{3}$ and $21.25 \mu \mathrm{g} / \mathrm{m}^{3}$ respectively and ANOVA P-value of 0.017 . Quarry workers in the crushing section were more exposed to dust (PM2.5 $\mu \mathrm{g} / \mathrm{m}^{3}$ ) especially at Ntake with a maximum dust emission of $48 \mu \mathrm{g} / \mathrm{m}^{3}$ followed by Halai with $43 \mu \mathrm{g} / \mathrm{m}^{3}$ on a sunny days.

Table 2: Variation of dust emission between processes on rainy and sunny days

\begin{tabular}{lllll}
\hline \multicolumn{5}{l}{ Mean dust emission measurements $(\mathrm{PM} 2.5 \mu \mathrm{g} / \mathrm{m} 3)$} \\
\hline Quarries & Sunny days & & Rainy days & \\
\hline Stirling & Crushing & Drilling & Crushing & Drilling \\
\hline Ntake & 28 & 23 & 28 & 17 \\
\hline Seyani & 48 & 28 & 30 & 20 \\
\hline Halai & 40 & 26 & 34 & 27 \\
\hline Min & 43 & 30 & 27 & 21 \\
\hline Max & 28 & 23 & 27 & 17 \\
\hline Mean & 48 & 30 & 34 & 27 \\
\hline Stdev & 39.75 & 26.75 & 29.75 & 21.25 \\
\hline COV & 9 & 3 & 3 & 4 \\
\hline ANOVA P-value & $=0.028^{*}$ & 11 & 10 & 20 \\
\hline WHO & 21 & & $=0.017^{*}$ & \\
\hline
\end{tabular}

WHO, (2005) permissive level for PM2.5 $\mu \mathrm{g} / \mathrm{m} 3$ is $25 \mu \mathrm{g} / \mathrm{m} 3$

Although, lower amounts of PM2.5 $\mu \mathrm{g} / \mathrm{m}^{3}$ were recorded on rainy days, all the quarry sites recorded higher levels of emission beyond the maximum recommended level of $25 \mu \mathrm{g} / \mathrm{m}^{3}$ by WHO, (2005) [27]. The mean level for dust emission at Seyani quarry on rainy days was recorded highest at $34 \mu \mathrm{g} / \mathrm{m}^{3}$ followed by Ntake with $30 \mu \mathrm{g} / \mathrm{m}^{3}$. This further revealed that quarry workers are exposed to high levels of pm2.5 \& 10 other associated health risks in case one has partial Personal Protective Equipment (PPEs) especially those in crushing section on sunny days. On rainy days, the mean dust emission levels during drilling at Stirling, Ntake, Halai were $17 \mu \mathrm{g} / \mathrm{m}^{3}, 20 \mu \mathrm{g} / \mathrm{m}^{3}$ and $21 \mu \mathrm{g} / \mathrm{m}^{3}$ below the permissive levels of $25 \mu \mathrm{g} / \mathrm{m}^{3}$ and only Seyani with mean dust emission exceeding the permissive levels of $25 \mu \mathrm{g} / \mathrm{m}^{3}$ [27]

\subsection{Pollution of water resources}

The results from laboratory analysis foe water quality are presented in the Table 3. The concentration of water quality parameters was observed to vary across the quarry sites. On the overall, the $\mathrm{pH}$ concentration in water across all the four active quarry sites 
were averaged at $\mathrm{pH} 5.5$ with a minimum value of $\mathrm{pH} 4.9$ at Ntake and a maximum of 6.18 at Halai. The average $\mathrm{pH}$ of 4.9 was below the standard national permissive levels for $\mathrm{pH}$ in the water of 6 to 8 as indicated in water quality guidelines by Uganda National Bureau of Standards [42]. The water that collects in the pits within the quarry sites during rainfall would later be released into the nearby environment and thus polluting the community water points (shallow wells). Water with less than the minimum permissive $\mathrm{pH}$ of 6 is associated with acidic characteristic According to the guidelines for drinking water quality by WHO, [29], consuming water of $\mathrm{pH}$ below 4, is associated with health implications such as soreness and irritation of eyes and the severity escalates with decreasing $\mathrm{pH}$. Below pH 2.5, damage to the epithelium is irreversible and extensive.

The laboratory tests for EC at all quarry sites returned values of $313 \mu \mathrm{S} / 1$ for Halai, $207 \mu \mathrm{S} / 1$ for Stirling, $171 \mu \mathrm{S} / 1$ for Ntake, $664 \mu \mathrm{S} / 1$ for Seyani, and $54.7 \mu \mathrm{S} / 1$ and 5.09 $\mu S / 1$ for the two neighbouring shallow wells. However, all these values are below the critical threshold levels of 2,500 $\mathrm{SS} / 1$ for EC recommended by UNBS, [42] water quality guidelines. According to the interpretation and standards of water quality parameters by the United States Environmental Protection Agency [43] water below the threshold of 2500 $\mu \mathrm{S} / \mathrm{l}$ has a lower level of ionic concentration activity due to small dissolved solids and thus less aggressive.

The results for turbidity at all quarry sites were below critical threshold levels of 300 (NTU). For example, $6 \mathrm{mg} / 1$ for Halai, $6 \mathrm{mg} / 1$ for Stirling, $25 \mathrm{mg} / 1$ for Ntake and 12mg/l for Seyani. Those for the two neighbouring shallow wells were $207 \mathrm{mg} / \mathrm{l}$, and $12 \mathrm{mg} / \mathrm{l}$. Water in the area especially at Halai and Stirling was associated with low turbidity levels which enhance satisfactoriness to consumers as well as its utility in certain Nakisunga.

The concentration of nitrates across all the quarry sites and one shallow well had values above threshold levels of $20 \mathrm{mg} / 1$ with an average of $237.1 \mathrm{mg} / 1$. Nitrate concentration above $20 \mathrm{mg} / \mathrm{l}$ is an indication that during drilling and blasting a lot of ammonium nitrate fuel is used.

Values of nitrite across the four active quarry sites and two shallow wells, were below the critical threshold levels of $2 \mathrm{mg} / \mathrm{l}$. For instance, it was $0.38 \mathrm{mg} / \mathrm{l}$ for Halai, $1.27 \mathrm{mg} / \mathrm{l}$ for Stirling, $0.068 \mathrm{mg} / \mathrm{l}$ for Ntake, $1.27 \mathrm{mg} / \mathrm{l}$ for Seyani, and $0.18 \mathrm{mg} / 1,0.008 \mathrm{mg} / 1$ for the two shallow wells respectively.

Levels of Iron (total) across the quarry sites and two quarry wells showed values below the critical threshold of $10 \mathrm{mg} / 1$ for examples $0.1 \mathrm{mg} / 1$ for Halai, $0.07 \mathrm{mg} / 1$ for Stirling, $0.13 \mathrm{mg} / 1$ for Ntake, $0.09 \mathrm{mg} / \mathrm{l}$ for Seyani, and $4.5 \mathrm{mg} / 1,0.35 \mathrm{mg} / 1$ for the two shallow wells.

Total Suspended Solids across the quarry sites indicated values below the critical threshold of $100 \mathrm{mg} / 1$ (6mg/l for Halai, $16 \mathrm{mg} / \mathrm{l}$ for Stirling, 14mg/l for Ntake, and 10.8mg/l for Seyani). However, one of the shallow wells (SW1) showed a value above the critical threshold (112mg/l). Higher concentrations of suspended solids can serve as carriers of toxics, make drinking water unpalatable and might have an adverse effect on people who are not used to drinking such water.

Table 3: Water quality analysis for quarry pits and nearby shallow wells

\begin{tabular}{|c|c|c|c|c|c|c|c|c|c|c|}
\hline \multirow{2}{*}{$\begin{array}{l}\text { Water quality } \\
\text { Parameter }\end{array}$} & \multicolumn{4}{|c|}{ Rainwater from the quarry pits } & \multicolumn{2}{|c|}{$\begin{array}{l}\text { Neighbouring } \\
\text { shallow wells }\end{array}$} & \multicolumn{3}{|c|}{ Statistics } & \multirow{2}{*}{$\begin{array}{l}\text { National Stand- } \\
\text { ards } \\
\text { (UNBS, 2017) } \\
\text { Levels }\end{array}$} \\
\hline & Halai & Stirling & Ntake & Seyani & SW1 & SW2 & Min & $\operatorname{Max}$ & Mean & \\
\hline $\mathrm{pH}$ & 6.18 & 5.74 & 4.87 & 5.65 & 5.28 & 5.09 & 4.9 & 6.18 & 5.5 & $6.0-8.0$ \\
\hline
\end{tabular}




\begin{tabular}{|c|c|c|c|c|c|c|c|c|c|c|}
\hline $\mathrm{EC}$ & 313 & 207.1 & 171.3 & 664 & 44.9 & 54.7 & 44.9 & 664 & 242.5 & 2,500 \\
\hline Turbidity (NTU) & 6 & 6 & 25 & 12 & 207 & 12 & 6.0 & 207 & 44.7 & 300 \\
\hline Nitrates(mg/1) & 199 & 188 & 148.4 & 855.6 & 0 & 31.6 & 0.0 & 855.6 & 237.1 & 20 \\
\hline Nitrites(mg/1) & 0.38 & 1.27 & 0.068 & 1.27 & 0.18 & 0.01 & 0.0 & 1.27 & 0.5 & 2 \\
\hline Iron $(\mu \mathrm{g} / 1)$ & 0.1 & 0.07 & 0.13 & 0.09 & 4.5 & 0.35 & 0.1 & 4.5 & 0.9 & 10 \\
\hline TSS(mg/1 ) & 6 & 16 & 14 & 10.8 & 112 & 12 & 6.0 & 112 & 28.5 & 100 \\
\hline TDS(mg/1 ) & 360 & 236 & 206 & 872 & 120 & 120 & 120.0 & 872 & 319.0 & 1200 \\
\hline Lead(mg/1 ) & 0.02 & 0 & 0 & 0.0 .3 & 0 & 0 & 0.0 & 0.02 & 0.0 & 0.1 \\
\hline Chromium (mg/1) & 0.32 & 0.16 & 0.08 & 1.22 & 0.01 & 0 & 0.0 & 1.22 & 0.3 & 0.05 \\
\hline $\operatorname{Zinc}(m g / 1)$ & 0.39 & 0.11 & 0.03 & 0.64 & 0.01 & 0 & 0.0 & 0.64 & 0.2 & 5 \\
\hline
\end{tabular}

Key: $\mathrm{pH}=$ Hydrogen Potential, EC=Electric Conductivity, TSS=Total Suspended Solids, TDS=Total Dissolved Solids, NTU= Nephelometric Turbid-

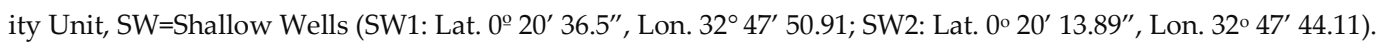

Total Dissolved Solids across the quarry sites and two shallow wells (SW1 and SW2) showed values below the critical threshold of $1200 \mathrm{mg} / 1$ being $360 \mathrm{mg} / \mathrm{l}$ for Halai, $236 \mathrm{mg} / \mathrm{l}$ for Stirling, 206mg/l for Ntake, $872 \mathrm{mg} / \mathrm{l}$ for Seyani and $120 \mathrm{mg} / \mathrm{l}$ for both shallow wells. Results for lead across the four active quarries and two shallow wells indicated values below detection level thus zero especially at Stirling and Ntake with only Seyani at $0.03 \mathrm{mg} / \mathrm{l}$ and Halai at $0.02 \mathrm{mg} / \mathrm{l}$ for whose results were below the critical threshold of $0.1 \mathrm{mg} / 1$ according to National standard levels of Lead in water advanced by UNBS, [42].

The concentration of chromium in the water across the four quarries showed values above National Standards for potable water of $0.05 \mathrm{mg} / 1$ with an average of $0.3 \mathrm{mg} / \mathrm{l}$. The values for zinc concentration in water across the four active quarries and two shallow wells were below the critical threshold of $5 \mathrm{mg} / \mathrm{l}$ for instance $0.39 \mathrm{mg} / \mathrm{l}$ for Halai, $0.11 \mathrm{mg} / 1$ for Stirling, $0.03 \mathrm{mg} / \mathrm{l}$ for Ntake, $0.65 \mathrm{mg} / \mathrm{l}$ for Seyani and $0.01 \mathrm{mg} / \mathrm{l}$ for the shallow wells.

\subsection{Mitigation measures put in place by quarry proprietors}
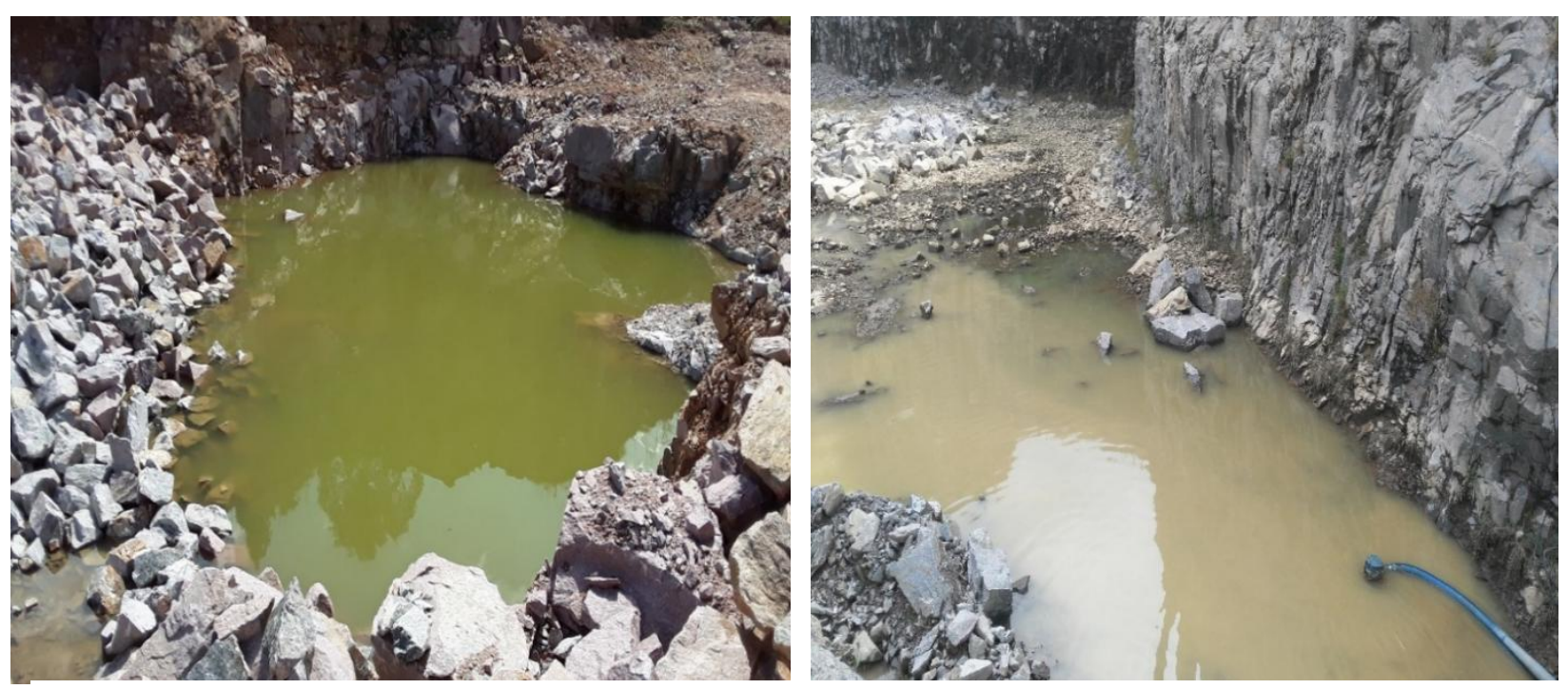

Figure 2: Rain water collected in the quarry pits awaiting discharge to the open environment 
Figure 3 below presents results of mitigation measures put in place at quarry sites to check on the undesirable effects of quarrying. Wet crushing and water sprinkling on bare surfaces measure was attested to be the most widely used across all the studied quarry sites with (68\%). Under a wet crushing system, the rock is moistened before crushing and this process happens within the grinder machine [19]. The quarry workers indicated that water sprinkling on bare surfaces is carried out when there is excessive dust generated especially in a dry season.

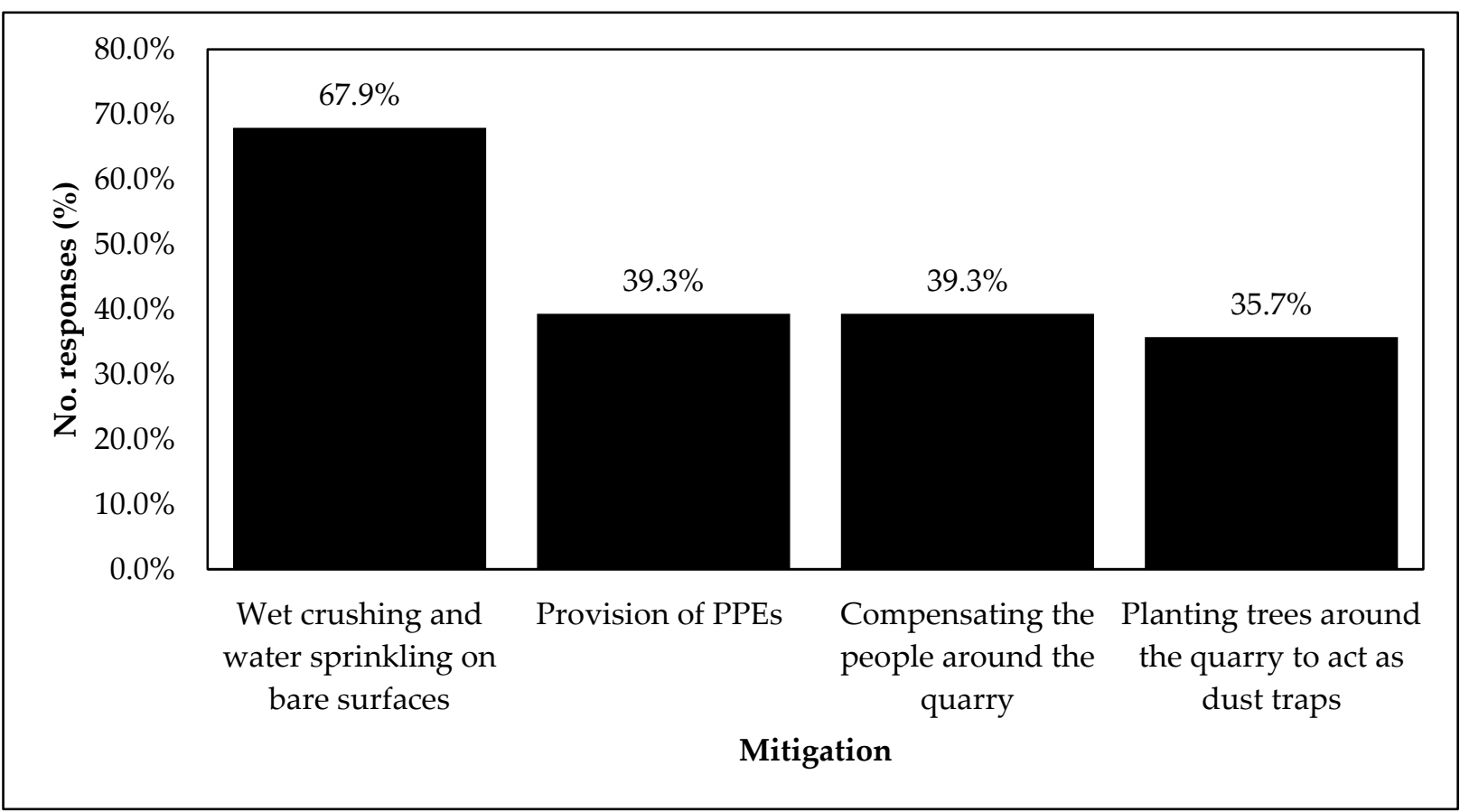

Figure 3: Mitigation measures put in place to minimize undesirable effects of quarrying to people within and around quarries.

\section{Discussion}

\subsection{Dust air pollution}

Air and water pollution was mainly due to the dust emission from crushing and drilling activities as also asserted by Bada et al., [22] during his study of air quality assessment in Jagun village, Ogun state in Nigeria. In addition, dust accumulation on plant leaves resulted in wilting leading to lowering of crop yields or failure in during a study on assessment of the environmental effects of Quarrying in Kitengela Subcounty of Kajiado in Kenya [4]. Furthermore, similar findings of dust water pollution in quarry communities are reported by a study on assessment of Environmental Impacts of Quarry operations in Ogun State, Nigeria where quarry operations were associated as reported by $44 \%$ and $44 \%$ for air pollution and water pollution [9]. The higher elements of dust emission in Nakisunga will cause threats of vegetal wilting especially during dry spells as reported by Akanwa et al., [44], that enormous vegetal wilting was caused by unsustainable quarrying practices in Ebonyi State, Nigeria. This thus limited the vegetal ecological functioning. Significant variation in dust air pollution and its implication between the studied quarry sites was due to the difference in the size and number of types of machinery such as crushers, wagon drillers, and heavy-duty trucks. Furthermore, major sources air pollution are quarrying related activities and vehicular emissions as well as wind-blown dust through unpaved roads in Jharkhand state of India [40]. 


\subsection{Dust Water pollution}

Results of high values of chromium in water of Nakisunga are in line with findings in a study on Socio-Economic and Environmental Impacts of Mining in Botswana: A Case Study of the Selebi-Phikwe Copper-Nickel Mine [45]. These also found out that Chromium was among the pollutants accrued from quarrying related activities in Botswana. Heavy metals such as chromium is poisoning to human health [46]. Also, high chromium contents in water is associated with skin irritation [43]. This may result into limited domestic water supplies in Nakisunga. Water pollution in form of high mean turbidity value $(44.7 \mathrm{NTU})$ and EC $(242 \mu \mathrm{S} / \mathrm{cm})$ were slightly higher than results advanced by $[47,48]$, where turbidity and EC were recorded high in water around quarry sites due to the inappropriate discharge of quarry pit water before drilling as well as inadequate liquid waste disposal.

Water had a mean Nitrates concentration of $(237.1 \mathrm{mg} / 1)$ higher than the permissive levels of $20 \mathrm{mg} / 1$. According to Ward et al.,[49], consuming much nitrate distorts blood oxygenation (also known as blue baby syndrome). Babies under six months old are at the highest risk of getting methemoglobinemia. This can further cause skin to turn a bluish colour and can result in serious illness or death. Other symptoms connected to methemoglobinemia include decreased blood pressure, increased heart rate, headaches, stomach cramps, and vomiting.

\subsection{Mitigation}

The mitigation measures found by the study were wet crushing and water spraying on bare ground as also reported by United states Department of Energy,[50] in it report on Water Application for Dust Control in the Central Plateau: Impacts, Alternatives. Besides water sprinkling was used for the reason that it was believed not only to reduce dust emission but also condense adverse impacts of dust both to quarry workers and the nearby environment [51]. This was also evidenced by the dust field measurements taken across dry and rainy days where dust emission (PM2.5) decreased to $27 \mu \mathrm{g} / \mathrm{m}^{3}$ for PM2.5 on a rainy day from $28 \mathrm{pm} 2.5$ on a sunny day during crushing. The higher dust emission on sunny days compared to rainy days accounts for the use of water sprinkling as a priority method of dust emission mitigation [52] who recommended use of water-mist while crushing and drilling as an efficient method of dust suppression in and around quarry sites.

\section{Conclusions}

Dust is a prominent implication of quarrying with its consequential effects air and water pollution especially during dry periods. There was a significant difference in dust emission across the studied quarry sites as well as between crushing and drilling especially in dry seasons or sunny days. Water pollution was majorly depicted through amounts of nitrates, chromium and $\mathrm{pH}$ that exceed permitted levels. Although inadequate, wet crushing and tree planting around the quarry sites were the most prioritized mitigation measure for dust suppression

Author Contributions: H.B, W.M \& A.M conceptualized the study and designed data collection methods; Y.K \& W.M performed the statistical analysis; W.M, \& Y. K writing original first draft manuscript; H.B, W.M \& Y.K review and editing \& H.B met the APA publication costs. Special 
thanks to the co-authors who have worked tirelessly to see that this research is published and the prompt inputs.

Source of Funding: This research has no external source of funding. We are grateful to the co-author W.M who solely provided funding for the data collection and analysis.

Conflicts of Interest: Authors declare no conflicting interest

Acknowledgements

This research would not have reached this far without the management of quarry sites of Seyani brothers company, Stirling, Ntake and Halai who permitted the research team to carry out the research within their quarry sites.

\section{References}

(1) National Planning Authority Uganda. Government of Uganda: Second National Development Plan; Uganda, 2015; Vol. 1, pp 6570.

(2) Hinton, J.; Lyster, O.; Katusiime, J.; Nanteza, M.; Naulo, G.; Rolfe, A.; Kombo, F.; Grundel, H.; MacLeod, K.; Kyarisiima, H.; Pakoun, L.; Ngonze, C.; Franks, D. M. Baseline Assessment and Value Chain Analysis of Development Minerals in Uganda. 2018.

(3) Eshiwani. Effects of Quarrying Activities on the Environment in Nairobi County: A Case Study of Embakasi District. Florence Eshiwani Reg No: C50/70641/2007 a Research Project Submitted in Partial Fulfillment of the Requirements for Master of Arts Degree in Environm, 2014.

(4) Mbandi, I. J. Assessment of the Environmental Effects of Quarrying in Kitengela Subcounty of Kajiado in Kenya. 2017, No. September.

(5) Akularemi. Assessing The Effects Of Stone Quarrying: The Case Of Wenchi Municipality In The Brong Ahafo Region Of Ghana, Kwame Nkrumah University of Science and Technology, 2015.

(6) MEMD. The Republic Of Uganda Ministry of Energy and Mineral Development Energy and Mineral Development Sector Sector Development Plan; 2015.

(7) UNDP. Baseline Assessment of Development Minerals in Uganda Baseline Assessment of Development Minerals in Uganda; 2018 ; Vol. 1.

(8) Oyediran, Wasiu Oyeleke and Omaore, A. M. Journal of Advance Research in Food, Agriculture and Environmental Science ISSN: 2208-2417. 2016, No. 2, 20-30.

(9) Mbuyi, M. Assessment of Environmental Impacts of Quarry Operation in Ogun State, Nigeria. J. Eng. Technol. 2017, 2 (2), 100-103. https://doi.org/engineering.fuoye.edu.ng/journa.

(10) Nartey, V. K.; Nanor, J. N.; Klake, R. K. Effects of Quarry Activities on Some Selected Communities in the Lower Manya Krobo District of the Eastern Region of Ghana. Atmos. Clim. Sci. 2012, 02 (03), 362-372. https://doi.org/10.4236/acs.2012.23032.

(11) Missanjo, E.; Ndalama, E.; Sikelo, D.; Kamanga-Thole, G. Quarry Dust Emission Effects on Tree Species Diversity in Chongoni Forest Reserve and Vegetation Characteristics in Adjacent Villages, Dedza, Malawi. Int. J. Inf. Rev. 2015, 2 (3), 511-515.

(12) Employment Act, 2006. Employement Act, 2006; GOU: Uganda, 2006; pp 1-52.

(13) National Environment Management Authority. National State of the Environment Report for Uganda 2014 ; Kampala, 2014. https://doi.org/http://www.nema.go.ug.

(14) United Nations Environment Programme. Analysis of Formalization Approaches in the Artisanal and Small-Scale Gold Mining Sector Based on Experiences In. 2012, No. June.

(15) Lad and Samat. Environmental And Social Impacts Of Stone Quarrying-A Case Study Of Kolhapur District. Int. J. Curr. Res. 2014, 6 (03), 2664-5669.

(16) Ming'ate, F.; Mohamed, M. Impact of Stone Quarrying on the Environment and the Livelihood of Communities in Mandera 
County, Kenya. J. Sci. Res. Reports 2016, 10 (5), 1-9. https://doi.org/10.9734/jsrr/2016/24945.

(17) Nanor, J. University of Ghana Http://Ugspace.Ug.Edu.Gh. 2011, No. 10297266.

(18) Bhatasara, S. Black Granite Mining and the Implications for the Development of Sustainability in Zimbabwe: The Case of Mutoko Communities. Environ. Dev. Sustain. 2013, 15 (6), 1527-1541. https://doi.org/10.1007/s10668-013-9456-y.

(19) National Institute for Occupational Safety and Health. Dust Control Handbook for Industrial Minerals Mining and Processing.; Pittsburgh, PA. Spokane, WA, 2012. https://doi.org/NIOSH Web site at www.cdc.gov/niosh.

(20) Sayara, T.; Hamdan, Y.; Basheer-salimia, R. Impact of Air Pollution from Quarrying and Stone Cutting Industries on Agriculture and Plant Biodiversity. Resour. Environ. 2016, 6 (6), 122-126. https://doi.org/10.5923/j.re.20160606.04.

(21) Amodu, Ayanda \& Adetunji, O. Environmental and Social Issues of Solid Mineral Development in Nigeria. 2016, No. October.

(22) Bada, B. S.; Olatunde, K. A.; Akande, O. A. Air Quality Assessment in the Vicinity of Quarry Site. Environ. Nat. Resour. Res. 2013, 3 (2). https://doi.org/10.5539/enrr.v3n2p111.

(23) Leon-Kabamba; Ngatu, Muzembo, B.; Kakoma, Kabamba, L. and H. Air Quality in the Working Environment and Respiratory Health of Female Congolese Stone Quarry Workers. 2020, 1-9.

(24) Peter, C.; Alozie, M.; Azubuine, C. Stone Quarrying Impact on Air Soil Water in Ebonyi State, Nigeria. J. Pollut. Eff. Control 2018, 06 (02), 2-5. https://doi.org/10.4172/2375-4397.1000225.

(25) Sana, S. . Cement Factories, Air Pollution And; 2013.

(26) Oyinloye, M. A.; Olofinyo, B. O. Environmental Impact of Quarry Activities on Resident of Akure Region, Nigeria. SCIREA J. Environ. 2017, 2 (2), 11-29.

(27) WHO, 2005. WHO Air Quality Guidelines Global Update 2005 Global. 2005, No. October.

(28) Yi, L.; Gao, B.; Liu, H.; Zhang, Y.; Du, C.; Li, Y. Characteristics and Assessment of Toxic Metal Contamination in Surface Water and Sediments near a Uranium Mining Area. Int. J. Environ. Res. Public Health 2020, 17 (2). https://doi.org/10.3390/ijerph17020548.

(29) WHO. Water for Health - WHO Guilines for Drinking-Water Quality. Who 2010, 1, 1-6.

(30) Wesaka, A. Http:/Www.Monitor.Co.Ug/News/National/Mukono-Residents-Want-Quarry-Company-Closed//688334/2334940/-/4d0pkoz/-/Index.Html. 2014, p 2334940.

(31) Ozean, O.; Musaoglu, N.; Seker, D. Z. Environmental Impact Analysis of Quarrying Activities Established on and near a River Bed by Using Remotely Sensed Data. Fresenius Environ. Bull. 2012, 21 (11), 3147-3153.

(32) NEMA. National State Of Environment Report For Uganda. NEMA: Kampala 2017.

(33) Sayara, T. Environmental Impact Assessment of Quarries and Stone Cutting Industries in Palestine : Case Study of Jammain. J. Environ. Prot. Sustain. Dev. Vol. 2016, 2 (4), 32-38.

(34) Tamale, S. The Impacts Of Stone Quarrying To The Local Community. Kampala International University., Kampala International University, 2014.

(35) MEMD. Mining Sector Profile for Uganda.; Kampala, 2018.

(36) MDLG. Higher Local Government Statistical Abstract for Mukono District; 2009.

(37) UBOS. National Population and Housing Census for Uganda, 2014. Natl. Popul. Hous. Census, 2014 2014, 1-73.

(38) UBOS. Uganda Bureau of Statistics (UBOS), National Population and Housing Census 2014; 2017.

(39) WHO. Definitions and Concepts. In Hazard Prevention and Control in the Work Environment: Airborne Dust; Princeton University Press: Geneva, Switzerland, 2014; pp 1-96.

(40) Bhanu, P.; Agrawal, M.; Singh, S. Assessment of Air Pollution around Coal Mining Area: Emphasizing on Spatial Distributions, Seasonal Variations and Heavy Metals, Using Cluster and Principal Component Analysis. Atmos. Pollut. Res. 2014, 5 (1), 79-86. https://doi.org/10.5094/APR.2014.010.

(41) APHA. American Public Health Association; American Water Works Association; Water Environment Federation. Stand. Methods Exam. Water Wastewater 1998, 02, 1-541. 
(42) UNBS. Draft Uganda Standard: Potable Water - Specification: DEAS 12: 2014; 2; Kampala, 2017.

(43) United States Environmental Protection Agency. Water Quality Standards Handbook. In Water quality standards handbook: Chapter 3: Water Quality Criteria; United States Environmental Protection Agency: EPA Office of Water, Office of Science and Technology, Washington, DC., 2017; pp 1-26. https://doi.org/https://www.epa.gov/eg/toxic-and-priority-pollutants-underclean-water-act.

(44) Akanwa, Angela \& Okeke, Francis \& Nnodu, Valerie \& Iortyom, E. (2017). Quarrying and Its Effect on Vegetation Cover for a Sustainable Development Using High-Resolution Satellite Image and GIS. Environmental Earth Sciences. 76. 10.1007/S12665-017-6844-Х.Вестник Росздавнадзора 2017, 4 (10.1007/s12665-017-6844-х.), 9-15. https://doi.org/76. $10.1007 / \mathrm{s} 12665-017-6844$.

(45) Darkoh, M. B. K.; Asre, B. K. Socio-Economic and Environmental Impacts of Mining in Botswana: A Case Study of the SelebiPhikwe Copper-Nickel Mine. East. Afr. Soc. Sci. Res. Rev. 2015, 17 (2), np.

(46) Divya Sapphire M., Sabaridasan A., Jesslin G., E. T. P. and S. Analysis of Water Quality Parameters and Heavy Metals Concentration Analysis of Water Quality Parameters and Heavy Metals Concentration from the Selected Sites of Tamiraparani River, Tirunelveli District, from the Selected Sites of Tamiraparani River, Tir. Int. Res. J. Environ. Sci. 2016, 5(7) (April 2017), $1-9$.

(47) Meride, Y.; Ayenew, B. Drinking Water Quality Assessment and Its Effects on Residents Health in Wondo Genet Campus, Ethiopia. Environ. Syst. Res. 2016, 5 (1), 1-7. https://doi.org/10.1186/s40068-016-0053-6.

(48) Mehmet, O. Environmental Pollution and Its Effect on Water Sources from Marble Quarries in Western Turkey. Environmental Earth Sciences. 75. 10.1007/S12665-016-5627-0. Turkey. 2016, 75. 10.100 (June), 12665.

(49) Ward, M. H.; Jones, R. R.; Brender, J. D.; de Kok, T. M.; Weyer, P. J.; Nolan, B. T.; Villanueva, C. M.; van Breda, S. G. Drinking Water Nitrate and Human Health: An Updated Review. Int. J. Environ. Res. Public Health 2018,15 (7), 1-31. https://doi.org/10.3390/ijerph15071557.

(50) United states Department of Energy. Water Application for Dust Control in the Central Plateau: Impacts, Alternatives, and Work Strategies; 2018.

(51) Pinder. An Assessment of Potential Air Quality Impacts. EA LTD, Swallow Barn, Stretton under Fosse, Warwickshire, CV23 0PE. UK July 2013, pp 1-29. https://doi.org/www.ea.ltd.uk.

(52) Murrow, B. R. Making bad quarry air bite the dust. https://doi.org/https://www.aggbusiness.com/ab3/feature/making-badquarry-air-bite-dust. 